https://www.journal-imab-bg.org

Original article

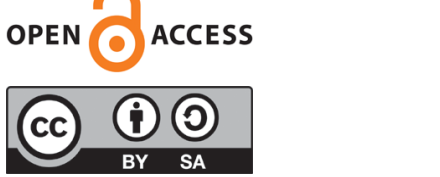

\title{
COMPARATIVE STUDY OF THE THERMAL EF- FECT OF TWO KINDS OF OPTIC FIBRES OF HIGH INTENSIVE 810 NM DIODE LASER (IN VITRO STUDY)
}

\author{
Raya Grozdanova-Uzunova, Elka Radeva, Dimitar Kosturkov, Evgeniya Popova, \\ Tsonko Uzunov \\ Department of Conservative Dentistry, Faculty of Dental Medicine, Medical \\ University, Sofia, Bulgaria.
}

\section{SUMMARY}

Purpose: The aim of our in vitro study is to investigate the thermal changes on the outer root surface that occur after irradiation with a high intensive diode laser with two types of optical fibers.

Material and Methods: The root canals of $24 \mathrm{ex}-$ tracted single-rooted and multi-rooted teeth (59 root canals) were prepared with Pro Taper Gold to F3 and treated with $810 \mathrm{~nm}$ diode laser for $8 \mathrm{~s}$ with circular movements from apex to orifices. Teeth are divided into two groups. A quartz light guide is used in the first group, and in the second group, the root canals are treated with an organically modified quartz light guide. The temperature changes were detected with FLIR - T 330 Infrared Thermal Camera and the data was processed with FLIR Reporter 9 Professional software.

Results: In $90 \%$ of cases, the temperature rise on the outer root surface is up to $8^{\circ} \mathrm{C}$. In the first group with quartz fiber, the minimum increase in temperature is $2^{\circ} \mathrm{C}$, the maximum is $11^{\circ} \mathrm{C}$ (in the cases with four root canals). When using the organically modified quartz fiber, the registered minimum increase in temperature is $1.2^{\circ} \mathrm{C}$ and maximum increase of $9.2^{\circ} \mathrm{C}$ (in cases with curved canals).

Conclusion: Temperature changes on the outer root surface using an $810 \mathrm{~nm}$ diode laser are biocompatible. There is no statistically significant difference between the temperatures measured in the two types of optical fibers used - quartz and organically modified quartz light.

Keywords: diode laser, light guide, outer root surface, thermal changes

\section{INTRODUCTION}

Various types of lasers are used in dental medicine in a number of procedures $[1,2]$. In practice, diode lasers are becoming more and more popular. They have good technical characteristics - they radiate over a wide range of electromagnetic radiation, have the ability to combine different resonance frequencies and wavelengths, ergonomic, longlasting and affordable [3, 4, 5]. Intra-canal high-energy diode lasers are used in endodontics. This is possible after preconditioning of the root canal to ensure unobstructed move- ment of the optical fiber. What matters is the depth of laser light propagation, as it can go beyond the apical opening and affect the periapical tissues. Thermal damage to the root and surrounding tissues is possible $[6,7]$.

The thermal effects of laser radiation in biological tissues depend on various factors: wavelength and tissue absorption, laser mode (tactile, impulse and Q-switching), energy or output power (single pulse/power $\mathrm{W} / \mathrm{cm}^{2}$ ), active time (e.g., pulse duration), repetition rate $(\mathrm{Hz})$, application method (contact / non-contact), the environment (blood, bone, hard dental tissues), coefficient absorption corresponding to the wavelength of the laser and thermal conductivity of exposed tissues [8,9].

In order to improve the direction of laser light distribution in the root canal, laser light conductors have been developed with different peaks - conical, lateral, honeycomb peaks. The conical end is formed on the basis of glass (quartz), including those doped with fluoride, germanium or gallium, using a pipe etching process to produce increased side emissions. These nozzles deliver more laser energy to the walls of the root canal than to the tip of the tooth [10]. The development of fiber-optic fibers, which are very thin and flexible, allows easier application of lasers in the root canal [11]. These are the organically modified quartz fibers.

\section{PURPOSE}

The purpose of our study is to measure the temperature changes on the outer root surface using two types of light conductors (quartz and quartz modified with organic inclusions) of a diode laser $810 \mathrm{~nm}$ at a maximum power of $1 \mathrm{~W}$.

\section{MATERIALS AND METHODS}

An in vitro study of 24 freshly extracted human teeth - single-root and multi-root (59 root canals in total) - without calcifications in the root canals. The root surface is cleaned of tartar, plaque and stains by periodontal curettes and the teeth are stored in physiological saline at room temperature $\left(20-25^{\circ} \mathrm{C}\right)$. Diagnostic X-rays were done and the teeth were autoclaved. The crowns of the teeth are removed by cutting with a diamond bur with a cylindrical-conical 
profile. A root canal length of $15 \mathrm{~mm}$ is standardized. The root canals are formed with rotary Ni-Ti files ProTaper Gold. The apical stop is reached up to F3 (Fig. 1). The final irrigation was made with $5.25 \%$ sodium hypochlorite and $17 \%$ EDTA.

Fig. 1. X-rays before and after preparation of root canals with ProTaper Gold
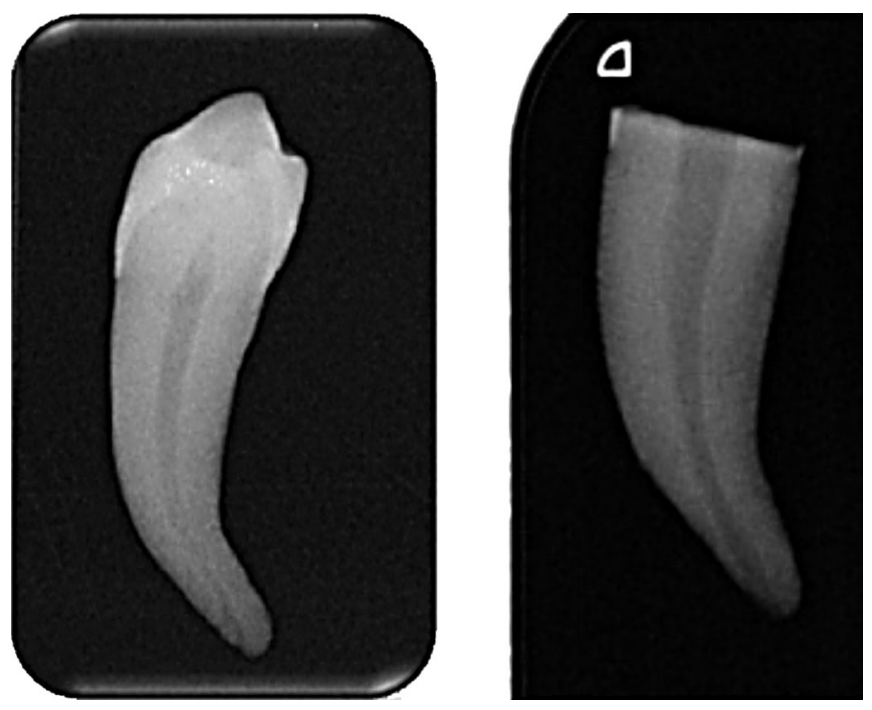

After the mechanical and chemical preparation of the root canals, the teeth are divided into 2 main groups, depending on the type of the light conductor used.

First group (quartz light conductor) - 12 teeth (36 root canals).

Second group (quartz light conductor, modified with organic inclusions) - 12 teeth (23 root canals).

The teeth are irradiated with DenLase diode laser at $810 \mathrm{~nm}$ wavelength (Fig. 2a) and a maximum power of $7 \mathrm{~W}$. The "Pulpotomy" protocol is used, with an average power of $1 \mathrm{~W}$ at maximum power for the $2 \mathrm{~W}$ protocol and pulse mode with $1 \mathrm{~ms}$ and $1 \mathrm{~ms}$ pause.

The first group is treated with a quartz light conductor with a diameter of $400 \mu \mathrm{m}$. The fiber is introduced $1 \mathrm{~mm}$ coronary from the specified working length and with helical movements for $8 \mathrm{sec}$ and is brought to the canal's orifice. In the multi-rooted teeth, the laser treatment was performed on the same protocol for each individual canal, and the thermography was also done for each canal separately.

In the second group, the laser treatment is made with a quartz light conductor, modified with organic inclusions (400 ìm in diameter) under the same parameters.

Fig. 2. DenLase diode laser (a) and FLIR T330 infrared camera (b)

Non-contact temperature measurement on the root surface was performed before and after the laser radiation with a Flir T 330 infrared camera (Fig. 2b) with an accuracy of $0.01{ }^{\circ} \mathrm{C}$. For this purpose, separate camera capture, respectively before and after the laser treatment, is made in
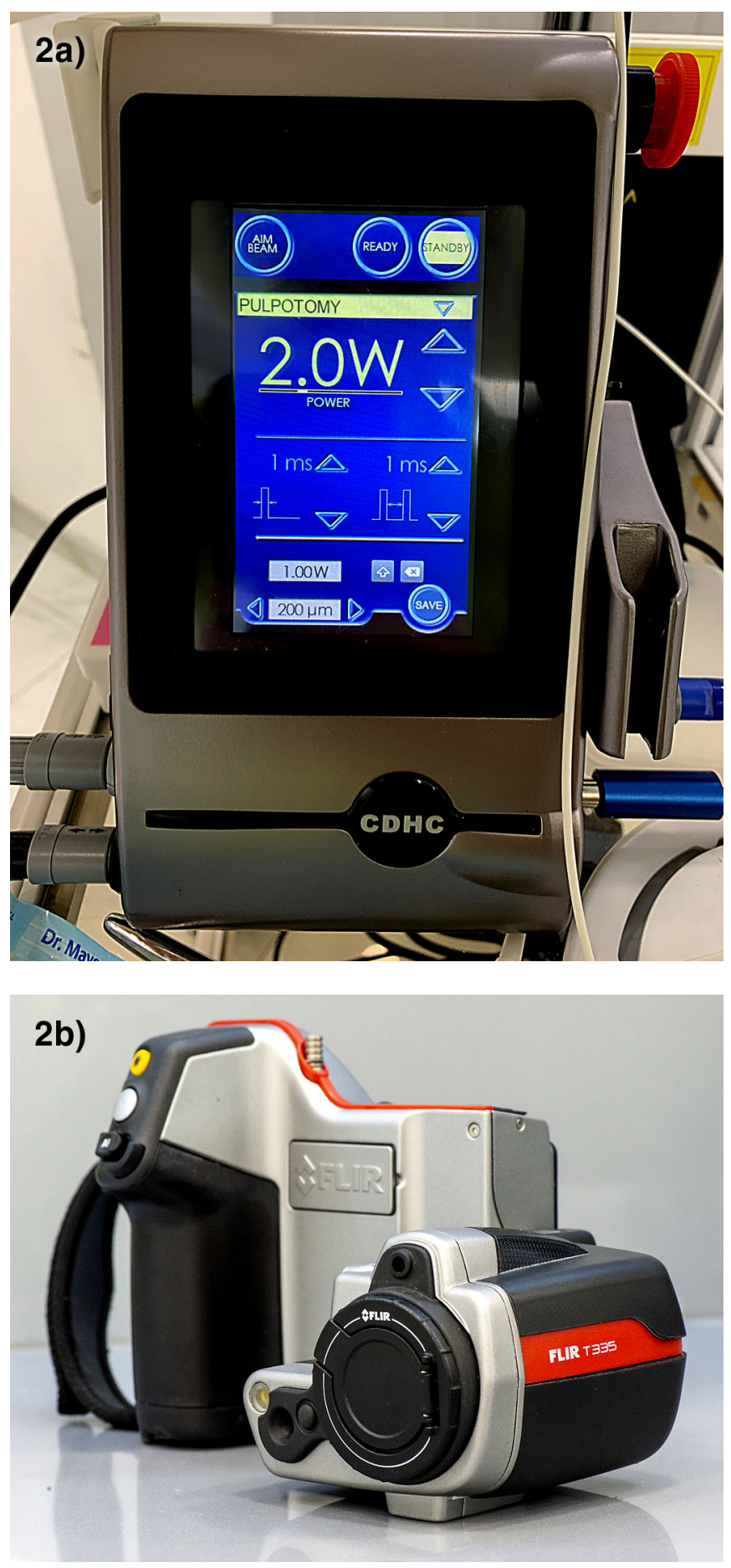

a thermally controlled environment. The resulting thermal images were analyzed by professional software FLIR Reporter 9 Professional, taking into account the highest temperature on the root surface before and after the laser treatment of each channel.

The results are statistically processed by a Paired Samples t-test, comparing two dependent groups in which the variable has a normal distribution. The accepted critical level of significance is $\alpha=0.05$. The corresponding zero hypotheses is rejected when the p-value is less than 0.05. The statistical data processing SPSS version 13.0 was used to process survey data and IBM Statistics SPSS v. 19. 


\section{RESULTS AND DISCUSSION}

The results of our study are shown in Table 1 . In $90 \%$ of cases, the rise in temperature on the outer root surface is up to $8^{\circ} \mathrm{C}$ (Fig. $\left.3-5\right)$.

In the existing literature, there are relatively few studies about periodontal tissue damage by overheating [5], as a $10^{\circ} \mathrm{C}$ rise in temperature is defined as a critical limit $[5,12,13]$.

Table 1. Measured temperature (temp.) before and after laser treatment of root canals with both types of fiber

\begin{tabular}{|c|c|c|c|c|c|}
\hline Tooth & First temp. $t^{\circ} \mathrm{C}$ & 1 st root & 2 nd root & $\begin{array}{l}3 \text { rd root } \\
4 \text { th root }\end{array}$ & DELTA temp. \\
\hline 1 - 1st group & 23,1 & 26,3 & 27,7 & - & 4,6 \\
\hline 2 - 1st group & 23,1 & 23,2 & 25,6 & - & 2,5 \\
\hline 3 - 1st group & 23,1 & 25,1 & 26,0 & 26,6 & 3,5 \\
\hline 4 - 1st group & 23,4 & 24,7 & 25,2 & 25,4 & 2,0 \\
\hline 5 - 1st group & 22,5 & 23,7 & 27,0 & $\begin{array}{l}27,2 \\
33,5\end{array}$ & 11,0 \\
\hline 6 - 1st group & 23,2 & 23,6 & 26,4 & $\begin{array}{l}30,2 \\
32,9\end{array}$ & 9,7 \\
\hline 7 - 1st group & 23,1 & 26,7 & 27,8 & - & 4,7 \\
\hline 8 - 1st group & 23,0 & 24,2 & 25,6 & - & 2,6 \\
\hline 9 - 1st group & 22,5 & 26,1 & 27,0 & 27,1 & 4,7 \\
\hline 10 - 1st group & 23,4 & 24,0 & 24,7 & 25,9 & 2,5 \\
\hline 11 - 1st group & 22,5 & 23,0 & 25,5 & $\begin{array}{l}27,2 \\
32,4\end{array}$ & 9,9 \\
\hline 12 - 1st group & 23,0 & 23,6 & 26,4 & $\begin{array}{l}30,2 \\
31,0\end{array}$ & 8,0 \\
\hline 13 - 2nd group & 22,2 & 22,8 & 24,0 & - & 1,8 \\
\hline 14 - 2nd group & 23,8 & 25,7 & - & - & 1,9 \\
\hline 15 - 2nd group & 25,5 & 28,7 & - & - & 3,2 \\
\hline 16 - 2nd group & 23,8 & 26,8 & - & - & 3,0 \\
\hline 17 - 2nd group & 23,3 & 23,7 & 29,1 & 30,3 & 7,0 \\
\hline 18 - 2nd group & 26,0 & 25,6 & 26,1 & 28,1 & 2,1 \\
\hline 19 - 2nd group & 22,7 & 24,2 & 25,7 & 26,2 & 3,5 \\
\hline 20 - 2nd group & 22,2 & 26,2 & 31,4 & - & 9,2 \\
\hline 21 - 2nd group & 28,5 & 29,7 & - & - & 1,2 \\
\hline 22 - 2nd group & 22,2 & 26,2 & 30,4 & - & 8,2 \\
\hline 23 - 2nd group & 23,0 & 23,7 & 29,1 & 30,4 & 7,1 \\
\hline 24 - 2nd group & 23,8 & 26,8 & - & - & 3,0 \\
\hline
\end{tabular}

When using quartz fiber, the minimum increase in temperature is $2^{\circ} \mathrm{C}$, the maximum is $11^{\circ} \mathrm{C}$ (Fig. 3 and 4 ). In one case, the temperature rise exceeds the biologically safe value for the periapical area of $10^{\circ} \mathrm{C}$, with the impression that it is a tooth with four root canals. It should be taken into consideration that the roots are thinner and the laser radiation is done in closely spaced areas.

Using the organically modified quartz fiber, the registered minimal increase in temperature was $1.2^{\circ} \mathrm{C}$ and the increase was $9.2^{\circ} \mathrm{C}$ (Fig. 5). Registered single elevated temperature elevations can be explained by the presence of narrow and curved canals and the ability to impede the free movement of the fiber in the canal. 
Table 2. Comparative analysis with a paired sample t-test

Paired Samples Test

\begin{tabular}{|c|c|c|c|c|c|}
\hline & \multicolumn{5}{|c|}{ Paired Differences } \\
\hline & \multirow[b]{2}{*}{ Mean } & \multirow{2}{*}{$\begin{array}{c}\text { Std. } \\
\text { Deviation }\end{array}$} & \multirow{2}{*}{$\begin{array}{l}\text { Std. Error } \\
\text { Mean }\end{array}$} & \multicolumn{2}{|c|}{$\begin{array}{c}95 \% \text { Confidence Interval } \\
\text { of the Difference }\end{array}$} \\
\hline & & & & Lower & Upper \\
\hline Pair $11 \mathrm{gr}-2 \mathrm{gr}$ & 1,2083333 & 4,1353154 & 1,1937627 & $-1,4191207$ & 3,8357874 \\
\hline
\end{tabular}

\section{Paired Samples Test}

\begin{tabular}{|c|c|c|c|}
\hline & $\mathrm{t}$ & $\mathrm{df}$ & Sig. (2-tailed) \\
\hline Pair1 $1 \mathrm{gr}-2 \mathrm{gr}$ & 1,012 & 11 & 0,333 \\
\hline
\end{tabular}

Comparative analysis of the absolute values of the recorded temperature did not reveal a statistically significant difference between the two types of fibers (Table 2).

Fig. 3. Temperature on the outer root surface of a double-root tooth before the laser irradiation (a) and after irradiation of a first canal (b)
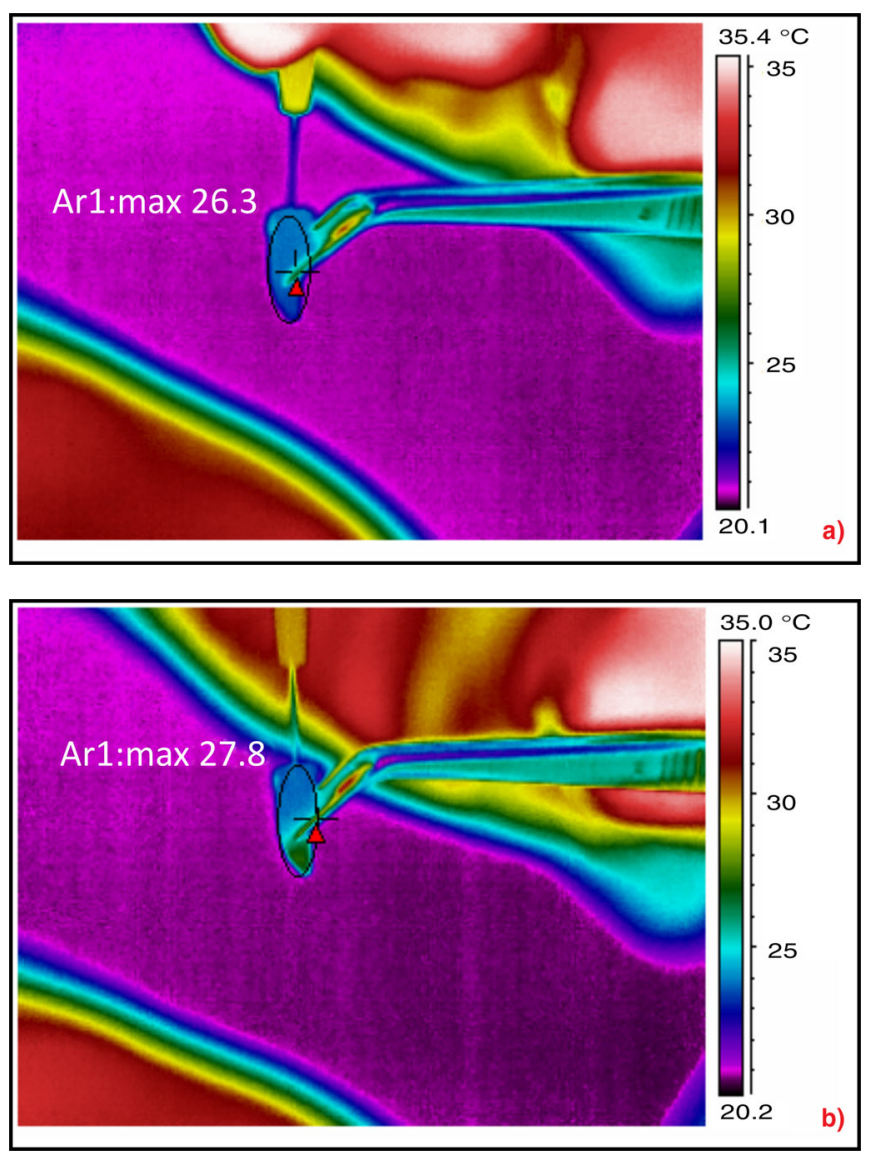

Fig. 4. Temperature on the outer root surface of a double-root tooth before the laser irradiation (a) and after irradiation of the second canal (b)
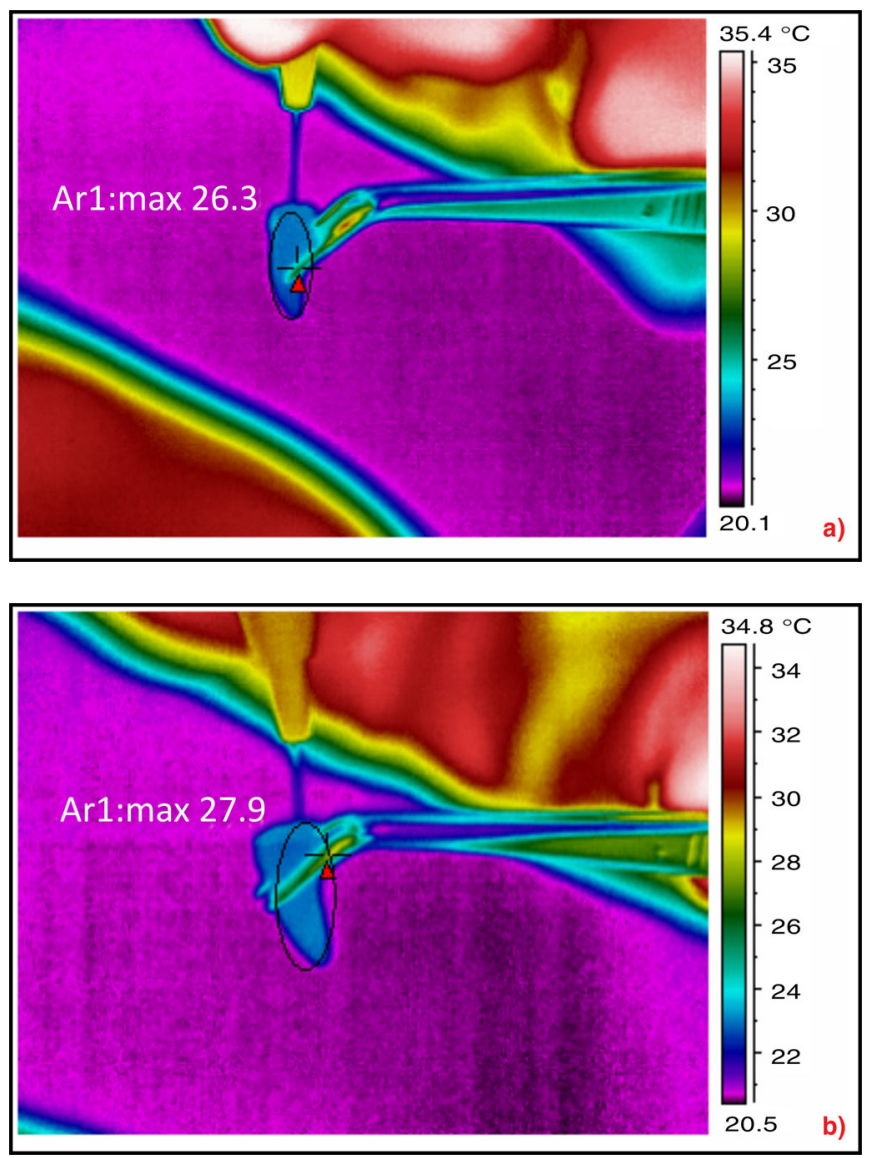

Our results are similar to those of an A. Moritz and collaborative in vitro study of the effects of a diode laser having a wavelength of $810 \mathrm{~nm}$ in the root canals of $40 \mathrm{ex}-$ tracts and stuffed teeth. They detect a rise in root surface temperature of no more than $6^{\circ} \mathrm{C}$ using a power of $4 \mathrm{~W}$ and pulses of 10 milliseconds and 10 milliseconds of rest. The root canal is irradiated 5 times for $5 \mathrm{sec}$. with spiral movements. The temperature changes are recorded by an infrared spectrometer [14]. In our study, we used infrared thermography - the FLIR T330 thermal camera. Infrared Thermogra- 
phy is a precise method for detecting the temperature in the facial area, in which one shot accurately records the temperature at all points of the subject under investigation [15].

Fig. 5. The outer root surface temperature of the multirooted tooth after the laser irradiation with the organically modified light guide of the first, second (b) and the third canal (c)
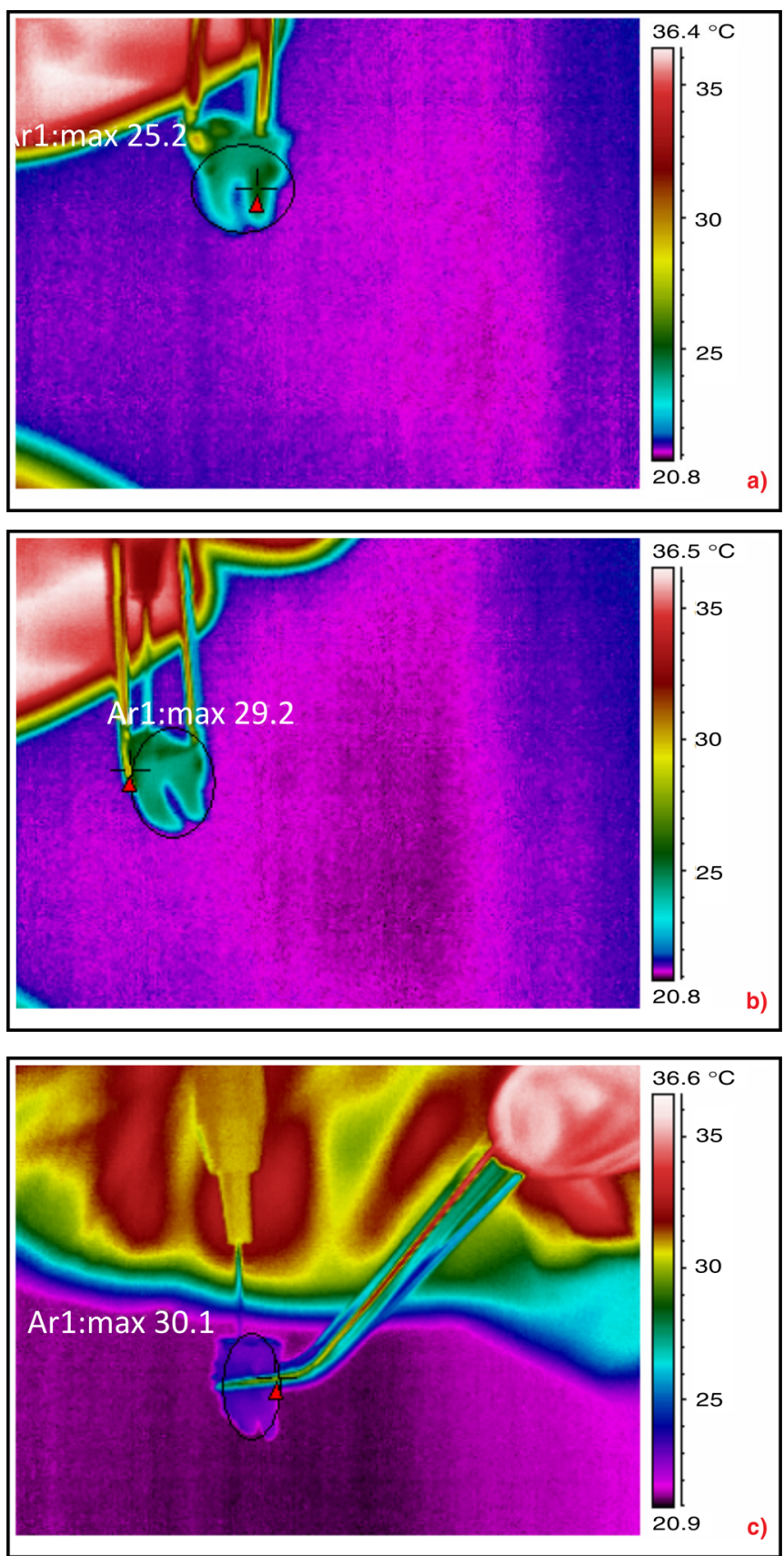

The results obtained by us and the registered biocompatible temperature changes on the outer root surface confirm the results of the study by A. Ribeiro and associates in 2007. They studied two workgroups using an 810 $\mathrm{nm}$ diode laser with different power of $1.25 \mathrm{~W}$ and $2.5 \mathrm{~W}$. For temperature recording, they used an infrared camera to detect a temperature increase in the range of 1.6 to $8.6^{\circ} \mathrm{C}$. higher power and from 1.2 to $3.3^{\circ} \mathrm{C}$ for the lower power group [16].
In another study on the application of the $810 \mathrm{~nm}$ wavelength diode laser, H. Gutknecht and colleagues studied the temperature changes on the root surface of 50 teeth after processing the channels of varying power - 0.6-1 $\mathrm{W}$ and $1-1.5 \mathrm{~W}$ - at steady mode and 1-1.5 W - for pulse mode with different interval settings. The temperature measured with NiCr-Ni sensors and thermometer T 202 and found that the temperature did not rise above $7^{\circ} \mathrm{C}$, which is safe for periodontal tissues, which is close to our results. The thickness of the optical fiber used in both tests is 400 microns [17]. The thickness of the fiber is important to avoid contact with the root surface and thus not contaminate and transfer the thermal effect to the space of the periodontal tissues [8]. The movement of the fiber with a circular motion from the apex to the coronary, which is observed in our study, according to a number of authors, ensures that the laser covers the entire inner wall of the canal and thus diminishes and avoids the melting of the dentine and the transfer of the thermal effect on the periodontal tissues $[8,18]$.

Laser energy is absorbed in surrounding tissues, so the impulse mode of work is particularly appropriate because it allows for thermal relaxation of the target tissue (it has time to cool before the next irradiation) [19].

From our results, we can see the direct dependence between the increase of temperature on the root surface and the thickness of the root walls. In teeth with more massive roots (upper central incisors, premolars, canines), the change is smaller, while in teeth with thinner roots (lateral incisors, multi-root teeth) larger. The thickness of the root wall also depends on the degree of processing - with pre-injection, a lower volume of hard dental tissues remains and this leads to an increase in temperature $[16,17]$.

During work, it is possible to pollute the tip of the fiber - it accumulates biofilm, which leads to more heat generation and a dramatic increase in temperature (holding the light conductor firmly on the dentin, which leads to its "activation"). When the tip of the light conductor is dirty, work should be cut off and the fiber should be cut.

The issue of elevated temperature on the root surface, given the biological tolerance and the risk of periodontal damage, is extremely topical. A large part of the thermal research reports the "biological tolerance" of the diode laser [20], temperature recording by thermocouples, infrared thermography and infrared spectrometry. Although single studies report, isolated cases of dangerous elevation of the temperature on the outer root surface. The analysis shows that this fact is found in its explanation with poor canal preparation, fiber retention in one place, or "fiber activation" upon contact with blood, resulting in a significant and risky rise in temperature.

\section{CONCLUSION}

The temperature changes on the outer root surface with $810 \mathrm{~nm}$ diode laser are within the range of the biotolerance - up to $10^{\circ} \mathrm{C}$. There is no statistically significant difference between the temperatures measured in the two types of optical fibers used - quartz and organically modified quartz. Further studies on the thermal effects of multi-root teeth are needed.

\section{Acknowledgements:}

The study is conducted under Contract No. D-88/ 03.05.2018, CMS, MU-Sofia. 


\section{REFERENCES:}

1. Convissar RA. Principles and Practice of Laser Dentistry. 2nd Edition. Mosby. 2015. Laser fundamentals, pp.14-20. [Internet]

2. Valente NA,Mang T, Hatton M, Mikulski L, Andreana S. Effects of Two Diode Lasers With and Without Photosensitization on Contaminated Implant Surfaces: An Ex Vivo Study. Photomed Laser Surg. 2017 Jul;35(7): 347-356. [PubMed] [Crossref]

3.Coluzzi DJ, Convissar RA. Atlas of Laser Applications in Dentistry. 1st Edition. Quintessence Pub Co. January 30, 2007. pp.1-7.

4.Renk KF. Basics of Laser Physics. For Students of Science and Engineering. Springer, Berlin, Heidelberg. 2012. Laser principle, $17-35$ p. [Crossref]

5. Saydjari Y, Kuypers T, Gutknecht N. Laser Application in Dentistry: Irradiation Effects of Nd:YAG $1064 \mathrm{~nm}$ and Diode $810 \mathrm{~nm}$ and $980 \mathrm{~nm}$ in Infected Root Canals-A Literature Overview. Biomed Res Int. 2016;2016:8421656. [PubMed] [Crossref]

6. Al-Karadaghi TS, Gutknecht N, Jawad HA, Vanweersch L, Franzen R. Evaluation of Temperature Elevation During Root Canal Treatment with Dual Wavelength Laser: $2780 \mathrm{~nm}$ Er,Cr: YSGG and $940 \mathrm{~nm}$ Diode. Photomed Laser Surg. 2015 Sep;33(9):460-6. [PubMed] [Crossref]

7.Beer F, Farmakis ET, Kopic J, Kurzmann C, Moritz A. Temperature Development on the External Root Surface During Laser-Assisted Endodontic
Treatment Applying a Microchopped Mode of a $980 \mathrm{~nm}$ Diode Laser. Photomed Laser Surg. 2017 Apr;35(4): 206-212. [PubMed] [Crossref]

8. El-Zohairy A, Serageldin RF. Synopsis is Using Dental Diode Laser in Endodontic. EC Dental Science. 2016 Nov; 5(4):1139-1144. [Internet]

9.Haidary D, Franzen R, Gutknecht N. Root Surface Temperature Changes During Root Canal Laser Irradiation with Dual Wavelength Laser (940 and 2780 nm): A Preliminary Study. Photomed Laser Surg.2016 Aug;34(8): 33644. [PubMed] ] Crossref]

10. George R, Walsh LJ. Laser Fiber-optic Modifications and Their Role in Endodontics. J Laser Dent. 2012; 20(1):24-30.

11. Moritz A, Schoop U. Lasers in Endodontics. In: Oral Laser Application. Moritz A. (Ed.) 1st Edition. Quintessence Publishing, Germany. 2006. Chapter 06. pp.241-313.

12. Alfredo E, Marchesan MA, Sousa-Neto MD, Brugnera-Junior A, Silva-Sousa YTC. Temperature variation at the external root surface during 980-nm diode laser irradiation in the root canal. J Dent. 2008 Jul;36(7):52934. [PubMed] [Crossref]

13. Todea CDM. Laser application in conservative dentistry. TMJ. 2004; 54(4):392-405.

14. Moritz A, Gutknecht N, Goharkhay K, Schoop U, Wernisch J, Sperr W. In vitro irradiation of infected root canals with a diode laser: Results of microbiologic, infrared spectrometric, and stain penetration examinations. Quintessence Int. 1997 Mar; 28(3):205-9. [PubMed]

15. Grozdanova R. [Thermodiagnostics of focal infection in the maxillofacial region.] [Disertation] Medical University, Sofia, Bulgaria. 2012. pp.191-209. [in Bulgarian]

16. da Costa Ribeiro A, Nogueira GE, Antoniazzi JH, Moritz A, Zezell DM. Effects of diode laser $(810 \mathrm{~nm})$ irradiation on root canal walls: thermographic and morphological studies. $J$ Endod. 2007 Mar;33(3):252-5. [PubMed] [Crossref]

17. Gutknecht N, Franzen R, Meister J, Vanweersch L, Mir M. Temperature evolution on human teeth root surface after diode laser assisted endodontic treatment. Lasers Med Sci. 2005 Sep;20(2):99-103. [PubMed] [Crossref]

18. Gutknecht N. Lasers in Endodontics. J Laser Health Academy. 2008; No.4:1-4.

19. Coluzzi DJ. Fundamentals of Lasers in Dentistry: Basic Science, Tissue Interaction, and Instrumentation. $J$ Laser Dent. 2008; 16(Spec. issue):4-10.

20. Valente NA, Calascibetta A, Patianna G, Mang T, Hatton M, Andreana S. Thermodynamic Effects of 3 Different Diode Lasers on an ImplantBone Interface: An Ex-Vivo Study With Review of the Literature. J Oral Implantol. 2017 Apr;43(2):94-99. [PubMed] [Crossref]

Please cite this article as: Grozdanova-Uzunova R, Radeva E, Kosturkov D, Popova E, Uzunov T. Comparative study of the thermal effect of two kinds of optic fibres of high intensive $810 \mathrm{~nm}$ diode laser (in vitro study). J of IMAB. $2021 \mathrm{Jan}-$ Mar;27(1):3523-3528. DOI: https://doi.org/10.5272/jimab.2021271.3523

Received: 26/09/2019; Published online: 15/01/2021

\section{Address for correspondence:}

Assoc. Prof. Elka Radeva, DMD, PhD

Department of Conservative Dentistry, Faculty of Dental Medicine, Medical University - Sofia,

1, St. Georgi Sofijski Str., 1431 Sofia, Bulgaria.

E-mail: eliradeva@abv.bg, 